Y, $\triangle \mathrm{K} 342.5$

ББК 67.400 .6

DOI 10.22394/1682-2358-2021-4-33-40

M.G. Shisbkin, post-graduate student at the Constitutional and International Law Department, SaintPetersburg University of Management Technologies and Economics

\section{FEDERAL DISTRICTS \\ IN RUSSIA: \\ PRACTICES \\ OF IMPROVING \\ PUBLIC \\ ADMINISTRATION}

Goals and reasons for the creation of federal districts in the Russian Federation and the institution of plenipotentiary representatives of the President of the Russian Federation in federal districts are studied. The problematics of the study is the current normative legal regulation of the federal districts functioning. The author proposes amending legislation on federal districts in order to systematize legal regulation in the sphere of interaction of public authorities located on a federal district territory.

Key words and word-combinations: constitution, federal districts, territorial structure.
М.Г. Шишкин, аспирант кафедры конституционного и международного права СанктПетербургского университета технологий управления и экономики (email: maks.schischkin2011@ yandex.ru)

\section{ФЕАЕРААЬНЫЕ ОКРУГА В РОССИИ: \\ ОПЫТ СОВЕРШЕНСТВОВАНИЯ ГОСУААРСТВЕННОГО УПРАВАЕНИЯ}

\footnotetext{
Аннотация. Исследуются цели и причины создания в Российской Федерации федеральных округов и института полномочных представителей Президента РФ в федеральных округах. Проблематику исследования составляет действующее нормативное правовое регулирование функционирования федеральных округов. Предложены изменения в законодательство о федеральных округах с целью систематизации нормативного правового регулирования в сфере взаимодействия органов публичной власти, расположенных на территории федерального округа.

Ключевые слова и словосочетания: конституция, федеральные округа, территориальное устройство.

K

началу 2000-х годов в России сложияась угрожающая ситуация - име$\Lambda и с ь$ все преАпосылки к распаду Российского государства. В состояние хаоса страну ввели действия как федерального центра, не имеющего четко сформулированной стратегии развития страны,
} 
так и стремление региональных элит получить как можно больше экономических благ.

В.В. Путин приступиц к исполнению обязанностей Президента РФ в марте 2000 г. и сразу обратил внимание на необходимость соблюдения руководством субъектов Федерации норм федерального законодательства. Аостичь указанной цели следовало в кратчайшие сроки, в связи с чем 13 мая 2000 г. был принят Указ Президента РФ (Аалее - Указ № 849), которым было утверждено Положкение «О полномочном представителе Президента Российской Федерации в федеральном округе» (далее - Положкение). Согласно Указу № 849, были образованы федеральные округа, объединяющие территориально несколько субъектов РФ, а на полномочного преАставителя Президента РФ в федеральном округе (далее - полномочный представитель) совместно с межрегиональными ассоциациями экономического взаимодействия субъектов РФ возцагается функция по разработке программ соџиально-экономического развития территорий [1] .

В.В. Путин подчеркивац, что федеральные округа образованы с целью укрупнения структур президентской вертикали в пределах определенных территорий, но не Аля укрупнения регионов [2]. Вместе с тем анализ

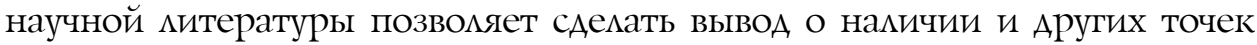
зрения относительно целей создания и функщионирования федеральных округов: одни исследователи связывают этот процесс с системой существовавших в то время военных округов; другие - с экономическим районированием, созданным в период сушествования СССР.

К.В. Черкасов отмечац, что в перспективе федеральный округ станет одним из элементов новой структуры государственного управления в Российской Федераџии, а именно: «федеральный центр - федеральные округа - субъекты Российской Федерации» [3, с. 74]. Такое мнение основывацось, помимо прочего, на проџессе укрупнения субъектов РФ, пик которого пришелся на 2003-2007 гг. (параА объединений), который проводияся в целях выравнивания экономической динамики регионов. В связи с этим в начале 2000-х годов ряА ученых выдвигац смелые суждения о скором изменении территориального устройства Российской Федерации с переходом к макросубъектам [4, с. 37]. ОАнако до сих пор в федеральных округах не сформированы органы вмасти с определенным правовым статусом, наличие которого предполагает преАоставление полномочий по принятию нормативных правовых актов. В соответствии с Указом № 849 субъекты РФ находятся в пределах федерального округа, а не переходят в его подчинение.

Кроме того, организационно-правовое преобразование субъектов Федерации в иные публично-территориальные образования с изменением их территориальных граниџ и конституционно-правового статуса потребует пересмотра действуюшей Конституции РФ [5]. При этом в

\section{Bulletin of the Volga Region Institute of Administration 2021. Vol. 21. № 4}


некоторых субъектах, включенных, к примеру, в состав Приволжского федерального округа, объединение респубцик и областей, конкурирующих межАу собой в разных сферах жизни, может иметь негативные последствия в целом Аля регионов.

Некоторые исследователи уверены, что федеральные округа созданы Амя разработки новых форм и методов управления федеративными отношениями, смягчения остроты вопросов асимметричности и многосубъектности Российской Федерации [6, с. 112] .

Более категорично по этому поводу высказывался Ю.И. Скуратов. По его мнению, Президент России осуществиц пересмотр фактически сложившихся конституционных отношений, не регламентированных законодательством [7, с. 43]. Иными словами, правовеА преАполагал Аолговременный характер проводимой реформы.

В.А. Аебедев, придерживаясь противоположной позиции, допускац, что институт полномочных преАставителей вводится на короткий временной промежкуток в целях преодоления кризисных явлений [8, с. 92].

Некоторые отечественные конституционалисты рассматривают феАеральные округа в качестве особых единиџ управления. К примеру, А.Ф. Багдасарян утвержАац, что федеральные округа - это государственные территориальные образования, целью создания которых должны стать, во-первых, совершенствование механизма политического управмения делами со стороны Российской Федераџии и, во-вторых, создание условий Аля разработки способов административного воздействия по реформированию федеративных отношений [9, с. 10].

По мнению К.В. Черкасова, федеральные округа представляют собой единство пространства определенных территорий, в пределах которых территориальные органы федеральных органов исполнительной власти осуществцяют предоставценные им полномочия [10, с. 8].

И.А. Акулич введение института полномочных представителей считает важнейшей предпосылкой возможности осуществления прямого президентского правления на местах в период кризиса [11, с. 264-265].

На наш взглял, образование федеральных округов в виде административно-управленческого звена связано прежде всего с необходимостью централизации власти в России. Именно поэтому полагаем ошибочным суждение К.В. Черкасова, рассматривавшего процесс создания федеральных округов в качестве элемента совершенствования механизмов федерахизации в России [12, с. 23-24] .

Слабость федерального центра во взаимодействии с субъектами ФеАерации при реализаџии закрепленных Конституџией РФ полномочий устанавцивалась нормативно. В частности, на основании ч. 3 ст. 11 Конституции РФ республики принудили федеральное руководство заключить Аополнительные договоры о разграничении предметов ведения и полно- 
мочий $[13$, с. 116] . По сообщениям Министерства юстищии РФ, к концу 1996 г. в девятнадцати из двадцати одной республиканских конституций содержались нормы, противоречащие Конституции РФ [14, с. 380] .

Э.М. Коломейцев справедливо отмечает, что образование федеральных округов было сигналом о том, что деятельность органов государственной власти субъектов РФ Аолжна быть поставлена под контроль федерального центра Амя обеспечения эффективности общего управления государством $[15$, с. 36$]$.

По мнению А.А. Аанько, полномочные представители, повышая эффективность государственного управления, осуществляют контроль наА исполнением решений, принятых федеральным центром, на территории федерального округа [16, с. 24].

Из изложенного можно сделать вывод, что главная цель создания федеральных округов заключалась в быстром подчинении органов государственной власти субъектов Федерации, в первую очередь руководителей, президентской воле по вопросам, относящимся к ведению Федерации, включая решение проблем общественной безопасности. Как известно, к тому времени оставался неразрешенным конфцикт на Северном Кавказе, который обусловливал приток в страну незаконных вооруженных формирований и невозможность контромя распространения их представителей с территории Чечни в иные субъекты РФ.

Вместе с тем Указ № 849, явмяющийся основой формирования особых территориальных единиц (федеральных округов) и создания специальных президентских структур координации и контроля (полномочные преАставители и их аппараты), не содержит определения понятия «федеральный округ», не раскрывает сущностное преАназначение федеральных округов и их место в территориальной структуре Российской Федерации. В конституционно-правовой доктрине также, к сожалению, не разработано общих подходов к природе федерального округа и его месту в системе государственного управления.

Таким образом, в Российской Федерации отсутствует конституционно-правовое регулирование вопросов создания и функционирования федеральных округов, а также деятельности полномочных представителей. Законодательно не закреплено определения понятия «федеральный округ», не регламентирован правовой статус полномочных преАставителей. Не закреплены эти понятия и в нормативных правовых актах субъектов РФ.

Положения Конституции РФ не содержат норм, посвященных феАеральным округам. Норма пункта «к» ст. 83 Конституции РФ, на наш взгляд, не предоставляет Президенту РФ права создавать какую-

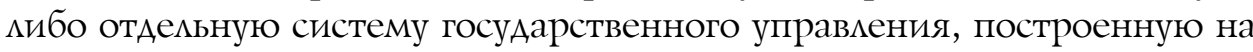


отношениях власти - подчинения. В связи с этим нельзя признать верным утверждение некоторых исследователей о том, что Президент РФ может создать систему округов, подобную судебным или военным округам [17, с. 58$]$.

Указом Президента РФ от 19 апремя 2017 г. № 177 «Об утверждении Положения о военном округе Вооруженных Сим Российской Федерации» [18] (Аалее - Указ № 177) образованы военные округа Вооруженных Сил РФ, которые явмяются основной военно-административной еАиницей Российской Федерации, межвидовым стратегическим территориальным объединением Вооружкенных Сил РФ. При этом цель создания военных округов состоит в осуществлении мер по подготовке к вооруженной защите и для вооруженной защиты целостности и неприкосновенности территории Российской Федерации в установленных границах ответственности.

Системно-структурный анациз норм ст. 19.2, 19.3 и 24 Федерального конституџионного закона от 31 декабря 1996 г. № 1-ФКЗ «О судебной системе Российской Федерации» (Аалее - Закон № 1-ФКЗ) [19] позволяет сделать вывоА, что судебный округ есть территория, в пределах которой окружной суА осуществляет отправление правосудия в соответствии с федеральным законом.

Итак, судебные и военные округа образованы в цемях упорядочения деятельности конкретных органов государственной власти (судов) и единиц управления (Вооруженных Сил) в определенных границах. Учреждение такого рода округов не затрагивает организацию федеративного устройства Российской Федераџии. В то же время отметим, что полномочия судов установиены Законом № 1-ФКЗ и соответствующими процессуальными кодексами, а органов военного управления - ФеАеральным законом от 31 мая 1996 г. № 61-Ф3 «Об обороне» [20], Указом № 177 и иными нормативными правовыми актами.

По нашему мнению, правовая природа и характер норм Конституции РФ позволяют прийти к выводу, что Основной Закон не предоставляет Президенту РФ столь широкого усмотрения при реализации права назначать своих полномочных представителей. Аанное право относится исключительно к сфере кадрового обеспечения деятельности государственных органов и домжностных Аиџ, подчиненных Президенту РФ. Образование Президентом РФ в граниџах Российской Федерации территорий, состав и возможность создания которых не закреплены конституционно, полагаем, выходит за рамки предоставленных главе государства полномочий.

Поскольку назначение подзаконного нормативного правового акта состоит в реализации мер, установленных законодательным актом, 
следует согласиться с предложкением В.Ю. Мазурова о необходимости принятия закона о федеральных округах [21, с. 26]. Считаем, что наиболее соответствует уровню рассматриваемой сферы отношений, а также положениям ч. 2 ст. 108 Конституции РФ принятие именно федерального конституционного закона, а не ординарного федерального закона. Это позволит субъектам Федерации в мице сенаторов выдвигать предложения, которые учитывают мнение регионов, особенности их развития и которые смогут стать нормами принятого федерального конституционного закона.

Безусловно, вопросы создания и функционирования федеральных округов Аолжны быть урегулированы федеральным конституционным законом. Вместе с тем полагаем необходимым сохранение института полномочных преАставителей, что обусловлено не в послеАнюю очередь отсутствием значимых успехов административной реформы 2003-2013 гг. [22, с. 15; 23, с. 39], результатом которой должно бымо стать повышение эффективности работы государственного аппарата в Российской Федерации.

Сушественной проблемой, на наш взгляА, явмяется и то обстоятельство, что в конституциях и уставах, а также в иных конституционных (уставных) актах субъектов РФ отсутствует какое- ибо упоминание о феАеральных округах и о полномочных представителях. В субъектах РФ не сформирована нормативно-правовая основа дмя взаимодействия региональных органов государственной власти и полномочных представителей.

В связи с этим предлагаем дополнить ст. 65 Конституции РФ частью 3 следующего содержания: «Территории субъектов РФ могут быть включены в состав федерального округа. Правовой статус федерального округа, иные условия его образования и сушествования определяются федеральным конституционным законом. Включение субъекта РФ в состав федерального округа не влечет утрату им правового статуса субъекта РФ». Аанное Аополнение обуславливает необходимость изменения содержания пункта «б» ст. 71 Конституџии РФ в части указания на то, что в ведении Российской Федерации также находится территория федеральных округов.

Аля привлечения субъектов РФ к Аеятельности полномочных преАставителей слеАует, на наш взгляА, Аополнить ст. 72 Конституции РФ, в которой перечислены предметы ведения, находящиеся в совместном регулировании Российской Федерации и субъектов РФ, пунктом «о.1» следующего содержания: «... общие вопросы взаимодействия органов государственной власти субъектов РФ с федерамьными органами государственной власти, органами местного самоуправления и полномочными представителями Президента Российской Федерации в федеральных округах».

После внесения соответствующих поправок в Конститущию РФ 
следует разработать, а затем принять Федеральный конституционный закон «О федеральных округах в Российской Федерации». Полагаем возможным закрепить в данном документе следующее определение федерального округа: «Федеральный округ - территория, включающая территории нескольких субъектов РФ, образованная в порядке, установленном настоящим федеральным конституционным законом, в целях осуществления социально-экономического и организационно-правового взаимодействия федеральных органов государственной власти, органов государственной вцасти субъектов, органов местного самоуправления, юридических и иных миџ, включая межрегиональные ассоциации экономического взаимодействия субъектов РФ».

При этом считаем важным оставить открытым перечень форм взаимодействия, предоставив субъектам Федерации право принятия своих нормативных правовых актов дмя установления таких форм. Это позволит учитывать разцичные особенности, присущие каждому без исключения субъекту РФ.

Таким образом, порядок создания и функщионирования федеральных округов и правовой статус полномочных представителей нуждается в системной законодательной, а не подзаконной регламентации. Аолжны быть установлены критерии создания федерального округа, четко определены права и обязанности полномочных представителей. Это будет способствовать повышению качества проџессов правотворчества и правоприменения ввиду минимизации комиизионных явлений, связанных с пересечением полномочий полномочных преАставителей, а также должностных миџ его аппарата (федеральные инспекторы, инспекторы) и органов государственной власти Российской Федерации и субъектов РФ. При этом деятельность полномочных преАставителей должна быть сведена к осуществлению координационно-контрольных функщий в соответствии с компетенцией, которой обладает Президент РФ.

\section{Библиографический список}

1. О полномочном представителе Президента Российской Федерации в федеральном округе: Указ Президента Российской Федерации от 13 мая 2000 г. № 849 (в ред. от 4 февр. 2021 г.) // Российская газета. 2000. 16 мая.

2. Путин В.В. Какую Россию мы строим // Российская газета. 2000. 11 июля.

3. Черкасов K.В. Федеральные округа в государственном устройстве России // Правовая культура. 2008. № 1(4). С. 69-80.

4. Бариии И.Н. Мысли об административной реформе в год десятилетия Конституции Российской Федерации // Федерализм. 2003. № 3. С. 35-44.

5. Конституция Российской Федерации (принята всенародным голосованием 12 дек. 1993 г. с изм., одобренными в ходе общероссийского голосования 1 июля 2020 г.). URL: https://legalacts.ru/doc/Konstitucija-RF/ 
6. Безруков А.В. Проблемы взаимодействия Российской Федерации и ее субъектов в сфере исполнительной власти // Журнал российского права. 2001. № 1. С. 110-117.

7. Скуратов Ю.И. Развитие Конституции Российской Федерации 1993 г.: поправки в Конституцию или конституционная реформа? // Российский юридический журнал. 2009. № 3. С. 40-47.

8. Лебедев В.А. Становление и развитие института полномочного представителя Президента Российской Федерации в федеральном округе // Вестник Университета имени О.Е. Кутафина (МГЮА). 2018. № 6 (46). С. 88-96.

9. Багдасарян А.Ф. Проблемы реформирования органов государственной власти в субъектах Российской Федерации, входящих в состав Северо-Кавказского федерального округа: автореф. дис. ... канд. юрид. наук: 12.00 .02 / Рос. ун-т дружбы народов. М., 2011.

10. Черкасов К.В. Федеральные округа в Российской Федерации: состояние и тенденции развития // Законодательство и экономика. 2009. № 1. С. 5-26.

11. Акулич И.А. Перспективы развития института полномочных представителей Президента РФ в федеральных округах: политический аспект // Научные ведомости Белгородского госуниверситета. 2012. № 1 (120). С. 261-265.

12. Черкасов K.В. Федеральные округа в механизме модернизации современного российского федерализма // Журнал российского права. 2008. № 8 (140). С. 19-24.

13. Шишкин М.Г. К вопросу об асимметрии субъектов Российской Федерации // Социология и право. 2020. № 4 (50). С. 113-118.

14. Kahn J. What is the New Russian Federalism? // Contemporary Russian Politics: a Reader. Oxford: Oxford University Press, 2001. P. 374-383.

15. Коломейчев Э.М. Федеральные округа в России: уникальный опыт административно-территориального устройства государства // Вестник Российского университета дружбы народов. Сер.: Политология. 2010. № 5. С. 35-40.

16. Данько А.А. Проблемы территориального устройства субъектов Российской Федерации: автореф. дис. ... канд. юрид. наук: 12.00.02 / МГУ им. М.В. Ломоносова. M., 2015.

17. Лапина М.А., Прохоров К.В. Федеральный округ как центр территориальных органов государственной власти // Юридический мир. 2010. № 6. С. 58-61.

18. Об утверждении Положения о военном округе Вооруженных Сил Российской Федерации: Указ Президента РФ от 19 апр. 2017 г. № 177 (в ред. от 5 нояб. 2020 г.) // С3 РФ. 2017. № 17. Ст. 2547.

19. О судебной системе Российской Федерации: Федер. конституционный закон от 31 дек. 1996 г. № 1-ФКЗ (в ред. от 8 дек. 2020 г.) // СЗ РФ. 1997. № 1. Ст. 1.

20. Об обороне: Федер. закон от 31 мая 1996 г. № 61-Ф3 (в ред. от 11 мая 2021 г.) // СЗ РФ. 1996. № 23. Ст. 2750.

21. Мазуров В.Ю. Федеральные округа в территориальной системе организации государственной власти в Российской Федерации: автореф. дис. ... д-ра юрид. наук: 12.00.02 / РАНХиГС при Президенте РФ. М., 2015.

22. Фельдман М.А. Административная реформа в России: продолжение следует // Вопросы управления. 2016. № 5 (42). С. 12-18.

23. Петров М.П. О необходимости концепции развития административной реформы в современной России // Вестник Пермского университета. Юридические науки. 2011. № 3 (13). С. 37-44. 